\title{
IAMJ
}

INTERNATIONAL

AYURVEDIC

MEDICAL JOURNAL

ISSN: 2320-5091

Impact Factor: 6.719

\section{EFFECT OF MURCHHIT TILA TAILA UTTARBASTI IN MANAGEMENT OF URETHRAL STRICTURE - A CASE STUDY}

\author{
Vineet Kini $^{1}$, S.D. Waghmare ${ }^{2}$, Shrikant Wakudkar ${ }^{3}$
}

${ }^{1}$ PG Scholar, Department of Shalyatantra, Government Ayurvedic College, Osmanabad, Maharashtra, India

${ }^{2}$ H.O.D \& Professor, Department of Shalyatantra, Government Ayurvedic College, Osmanabad, Maharashtra, India ${ }^{3}$ PG Scholar, Department of Shalyatantra, Government Ayurvedic College, Osmanabad, Maharashtra, India

Corresponding Author: vineetkini31@ gmail.com

\section{https://doi.org/10.46607/iamj3909122021}

(Published Online: December 2021)

Open Access

(C) International Ayurvedic Medical Journal, India

Article Received: 12/11//2021 - Peer Reviewed: 27/11/2021 - Accepted for Publication 06/12/2021

\section{Check for updates}

\begin{abstract}
In Geriatric patients, urological problems like dribbling micturition, burning micturition, dysuria etc. are commonly seen due to Urethral Stricture, BPH, Chronic urinary tract infection, Urinary Incontinence, Over-active bladder etc. In this study, we will discuss the effect of the Ayurvedic Panchkarma Procedure i.e., Uttarbasti in Urethral Stricture. Urethral Stricture involves scarring that narrows the tube that carries urine out of the body mostly due to STD's, Catheterisation, straddle injury to the perineum. Newer Surgical Techniques like Urethral Dilatation, DVIU, Urethroplasty etc are used but they are painful, expensive \& has recurrences. In Ayurvedic literature, Mutra margasankoch and Mutrotsanga are an entity that can be closely related to urethral stricture which is described by Acharya Sushruta in Uttartantra. In this case study, a 45-year-old male patient suffering from LUTS Came to Shalya OPD undergone repeated urethral dilatations but was unrelieved. So, after clinical evaluation \& Investigations, the case was diagnosed as Urethral Stricture \& treated with Uttarbasti. In this case study, Murchhit Tila Taila for the Uttarbasti procedure was used. After the Procedure results were evaluated \& the results are satisfying.
\end{abstract}

Keywords: Uttarbasti, Murchhit Tila Taila, Urethral Stricture 


\section{INTRODUCTION}

Ayurveda is the science of Life \& Originated in India more than 5000 years ago \& is often called "Mother of All Healing" Ayurveda is formally organized into 8 branches commonly known as "Asthang Ayurved". According to Acharya Sushruta, who is known as the Father of Indian Surgery Shalyatantra is the main branch, which deals primarily with knowledge of various surgical disorders with their causes, symptoms, diagnosis and management ${ }^{[1]}$. Acharya Sushruta described Mutraghata roga (Obstructive Urinary pathology) in Uttartantra. There are 12 varieties of Mutraghata is described in Sushruta Samhita. Mutramarg sankoch is not mentioned as a separate entity but the symptoms have similarities with Mutrotsanga ${ }^{[2]}$. In Mutrotsanga (Tardy flow of urine) the pathology must be in the urinary bladder or urethra anywhere from the bladder to the tip of the penis. Symptoms of $\mathrm{Mu}$ tramarg sankoch can be correlated with Stricture Urethra. Urethral Stricture means narrowing of the urethral lumen by a fibrotic tissue which obstructs the flow of urine \& produces LUTS like Dribbling micturition, hesitancy, urgency, dysuria etc ${ }^{[3]}$. The etiological factors may be chronic infection, post-surgery, trauma etc. ${ }^{[4]}$ In Modern Medicine modality of treatments include surgical techniques like Urethral Dilatation like Balloon \& Sequential Dilatation. Newer Modern Surgical techniques are presently in use like DVIU (Direct Visual Internal Urethrotomy), Urethroplasty, Urethral Meatal Stenting, Free Graft (Skin, Mucosal Lining of cheeks). Repeated instrumentation carries the risk of local trauma, false passage, formation of infection. ${ }^{[5]}$ Apart from Complications, these techniques are expensive $\&$ it is unable to provide satisfaction \& uneventful recovery. Acharya Sushruta described Uttarbasti under the heading of Shashtiupakrama ${ }^{[6]}$. Which is a unique treatment of Mutraghata Vyadhis. In this Procedure medicated oil, Decoction \& Grita are passed through Per Urethra in males \& in the Urinary bladder or Urethra in females. It is carried out as per the advancement of the disease. Previous studies also suggest encouraging results with different medicated oil. ${ }^{[7]}$

\section{Case Report}

A Male patient of 45 yrs old complains of Dribbling Micturition, Dysuria, increased frequency of micturition for the past 8 months.

\section{History of Present illness:}

The patient was asymptomatic before 10 months then started complaining of the above symptoms but since the symptoms were not so significant patient ignored it, but 3 months ago complaints got increased \& shown to a Urologist in Osmanabad. The patient has undergone Urethral dilatation \& Suprapubic catheterisation at the urology hospital but had no relief. So, for further, management the patient came to Shalyatantra OPD at GAC, Osmanabad.

\section{Past History:}

\section{Medicinal History: N/H/O DM/HTN /KOCHS/BA}

Surgical History: Circumcision at age of $13 \mathrm{yrs}$, Supra-public catheterization \& Urethral Dilatation done 4 months ago.

Family History: No relevant family history was noted Allergic History: None

\section{Personal History:}

Bowel: Irregular

Urine: Irregular

Diet: Mixed

Appetite: Regular

Occupation: Primary School teacher

Addiction: None

\section{Systemic Examination}

R.S: Air entry bilaterally Equal \& clear, No abnormal sounds

CVS: S1 S2 Normal, no abnormal cardiac sounds heard

CNS: Conscious, Oriented to time, Place \& Person.

\section{Local Examination:}

The patient is examined in a supine position along with genital examination.

-External urethral meatus stenosis is seen (Coronal Hypospadias)

-Penile Shaft normal curvature is seen.

-B/L Testis normally palpable

-Spermatic cord non-tender B/L Palpable

-No Inguinal Lymphadenopathy 


\section{Investigations:}

\section{CBC:}

Hb-12.1mg/dl; BT-2' 40"

WBC-8600; CT- 6' 70"

Platelets: -210000; VDRL-Negative

BSL (R) -84 mg /dl; HbsAg- Non -Reactive

ICTC-Non-Reactive

Urine Routine \& Microscopic S /O -No evidence of Sugar /Pus cells/RBC's \& Casts, Crystals

KFT: Sr. Urea- $23 \mathrm{mg} / \mathrm{dl}$

Sr. Creat- 1.51

Sr. Uric Acid -5.1

\section{Materials \& Method:}

In this study, $20 \mathrm{ml}$ of Murchhit Tila Taila was used for Uttarbasti. The dose may be varied from $10 \mathrm{ml}$ to $60 \mathrm{ml}$ depending upon the severity of the disease. Some other ingredients like rock salt were used in powder form in the amount of $1 \mathrm{gm}$. After mixing salt in oil make it warm enough to touch. Avoid too much heat as it may cause burn. Uttarbasti oil along with other required instruments like a disposable syringe, surgical gloves infant feeding tube 8 no, Xylocaine jelly,2 \% betadine swab \& some betadine gauze pieces, sponge holding forceps, hole sheet, the penile clamp was sterilized \& kept ready for the procedure.

Dose: Alternate-day Murchhit Tila Taila +1 gm Saindhav mixture Uttarbasti given to the patient for 10 days with a feeding tube, repeated after 10 days for 2 months.

Follow up: Taken at 2 months

Route: Per Urethra

Assessment Criteria:

A) Subjective Criteria

1)Weak Stream

\begin{tabular}{|l|l|l|}
\hline Sr. No & Grades & Symptoms \\
\hline 1 & 0 & Normal Stream \\
\hline 2 & 1 & Moderate stream falling $10 \mathrm{~cm}$ ahead of legs (After Study) \\
\hline 3 & 2 & Poor Stream falling near legs within $10 \mathrm{~cm}$ (Before Study) \\
\hline 4 & 3 & Dribbling Micturition soiling clothes \& body parts \\
\hline 5 & 4 & Acute Retention of Urine \\
\hline
\end{tabular}

\section{2)Hesitancy}

\begin{tabular}{|l|l|l|}
\hline Sr. No & Grades & Symptoms \\
\hline 1 & 0 & The normal flow of urine within 5 secs \\
\hline 2 & 1 & The flow of urine after straining for $5-10$ secs (After Study) \\
\hline 3 & 2 & The flow of Urine after straining for $10-15$ secs \\
\hline 4 & 3 & The flow of Urine seen after straining for more than 15 secs (Before Study) \\
\hline 5 & 4 & No flow of urine after straining for any time. \\
\hline
\end{tabular}

\section{3)Dysuria}

\begin{tabular}{|l|l|l|}
\hline Sr. No & Grades & Symptoms \\
\hline 1 & 0 & Normal Stream with no straining \& pain \\
\hline 2 & 1 & Moderate stream with mild straining \& pain (After Study) \\
\hline 3 & 2 & Poor Stream with moderate straining \& pain (Before Study) \\
\hline 4 & 3 & Dribbling with moderate straining \& pain \\
\hline 5 & 4 & No flow of urine despite severe straining \& pain \\
\hline
\end{tabular}




\section{B) Objective Criteria}

\section{1)Urine Flowmeter}

Observation \& Results:

\begin{tabular}{|l|l|l|l|}
\hline Sr. No & Symptoms & Before Treatment & After Treatment \\
\hline 1. & Weak Stream & 02 & 01 \\
\hline 2. & Hesitancy & 03 & 01 \\
\hline 3. & Dysuria & 02 & 00 \\
\hline 4. & Urine Flow/Sec & $5 \mathrm{ml} / \mathrm{sec}$ & $11 \mathrm{ml} / \mathrm{sec}$ \\
\hline
\end{tabular}

\section{DISCUSSION}

Urethral stricture is a commonly encountered disease in day-to-day surgical practice which is relatively common in men, reason can be attributed to testosterone which plays an important role in the development of the urethra \& function of the smooth muscles of corpora cavernosa, due to a decrease in androgen receptors \& periurethral vascularity in the urethra leading to increase in urethral stricture. The Management of urethral stricture disease over the last few decades has been mainly surgical like urethral dilatation which requires an expert hand to avoid complications like false passage \& journey of the treatment proves to be expensive. Urethroplasty which is considered a Gold Standard treatment, still patients come with recurrence after some years. Uttarbasti is an Ayurvedic panchkarma procedure advised by Sushruta in the management of Mutraghata and Mutrakrichra(Difficulty in Micturition). Mutramargasankoch is a disease that is caused by mainly Vata and Kapha Doshas and trauma to the urethral lining is one of the pathological factors in this disease. Uttarbasti procedure acts both ways i. e pharmacologically \& mechanically on the stricture urethra. Here in the study Murchhit Tila Taila has been used which easily gets absorbed by mucosa in the urinary bladder \& acts on urethral stricture. Murchhit Tila Taila is having the main properties Vata-Kaphagna. Murchhit Tila Taila possesses properties of Vyavahi, Sukshma \& Snigdha (smooth) Guna which helps in the Lubrication \& Dilatation of the Urethral Lumen. Also has properties like Snehan (Oleation) \& Sar which increases the elasticity of the tissues, penetrate deep tissues, help in wound healing and softening of the tissues. Also makes the Mutramarg smooth for the passage of urine and so less friction is present. The ingredients used for Murchana have their own therapeutic activity. Also, Saindhav used possess properties Chedana, Bhedana, Sara, Sukshama, Vikasi, Margvishodhankar, Sharir Avayamridukar, Vataanuloman, so it helps in the Lekhan karma (Scrapping) of the fibrosed tissues. Also, the Sukshama Guna of Saindhava (Rock Salt) helps to penetrate and act in the deeper tissues. Now come to the mechanical effect of Uttarbasti as due to frequent insertion of an infant feeding tube in increasing sizes mechanically dilates the contracted part so that lumen remains open that reflect an as good stream of urine. The above mode of action of drug results in no stasis of urine reduces chances of UTI \& Ultimately results in no recurrence of urethral stricture.

\section{CONCLUSION}

The case study concluded that Murchhit Tila Taila Ut tarbasti is as good as some of the Modern surgery techniques that are widely accepted globally. There is lesser evidence of Recurrence with Murchhit Tila Taila Uttarbasti with almost no complications such as bleeding or false tract.

It is a minimal invasive economical \& cost-effective treatment available for Urethral stricture and can be easily performed in the Indian OPD set-up of the Hospital.

\section{REFERENCES}

1. Ambikadatta Shastri, Sushruta Samhita -1, Sutrasthan 1/7, Varanasi Chaukhambha Sanskrit Sansthan ;(Reprint 2015): p.5

2. Ambikadatta Shastri, Sushruta Samhita, Uttartantra 58/3,4, $i$;(Reprint 2015): p.539 
3. Shriram Bhat M, SRB's Manual of Surgery, $5^{\text {th }}$ edition New Delhi, Jaypee brother's medical publisher(p) Ltd, (March 2017), chapter 26 $6^{\text {th }}$ urology: 1055

4. K Rajgopal Shenoy, Anita Shenoy, Manipal Manual of Surgery, $4^{\text {th }}$ edition, New Delhi, CBS Publishers \& amp; Distributors Pvt. Ltd, (2014):964

5. S. Das, A Concise Textbook of Surgery $10^{\text {th }}$ edition, Kolkata-700005 Old Mayors Court, (2018):1301

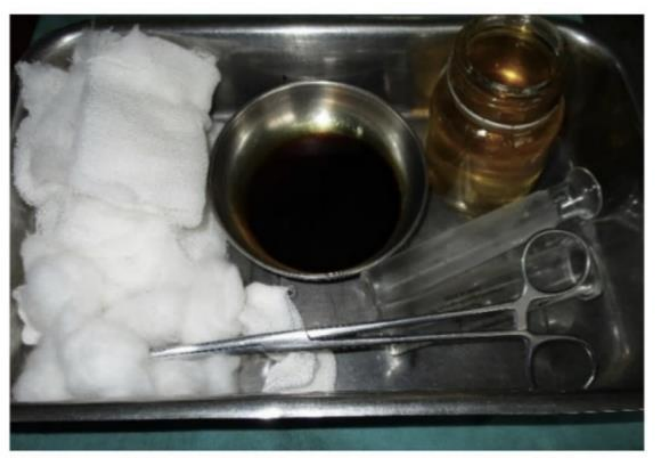

EQUIPMENT FOR UTTARBSTI.
6. Ambikadatta Shastri, Sushrut Samhita, Chikitasthana 1/110, Varanasi Chaukhambha Sanskrit Sansthan ;(Reprint 2005): p.15

7. Amilkanthwar RH. Role of Uttarbasti in the management of Mutra Marga Sankoch (Urethral Stricture). Indian J Tradit Knowl.2004;177-81

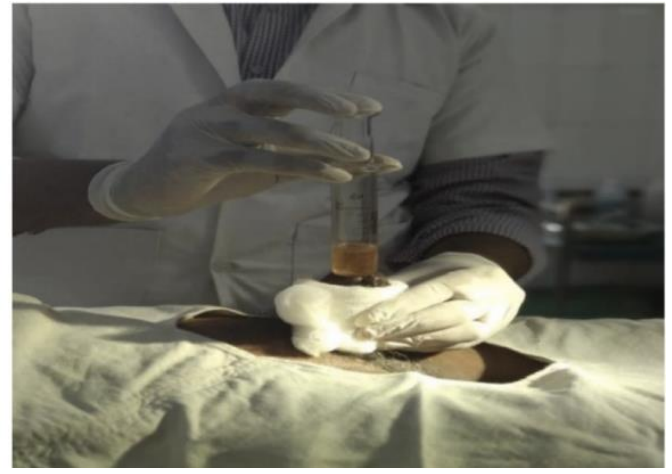

PROCEDURE UTTARBASTI
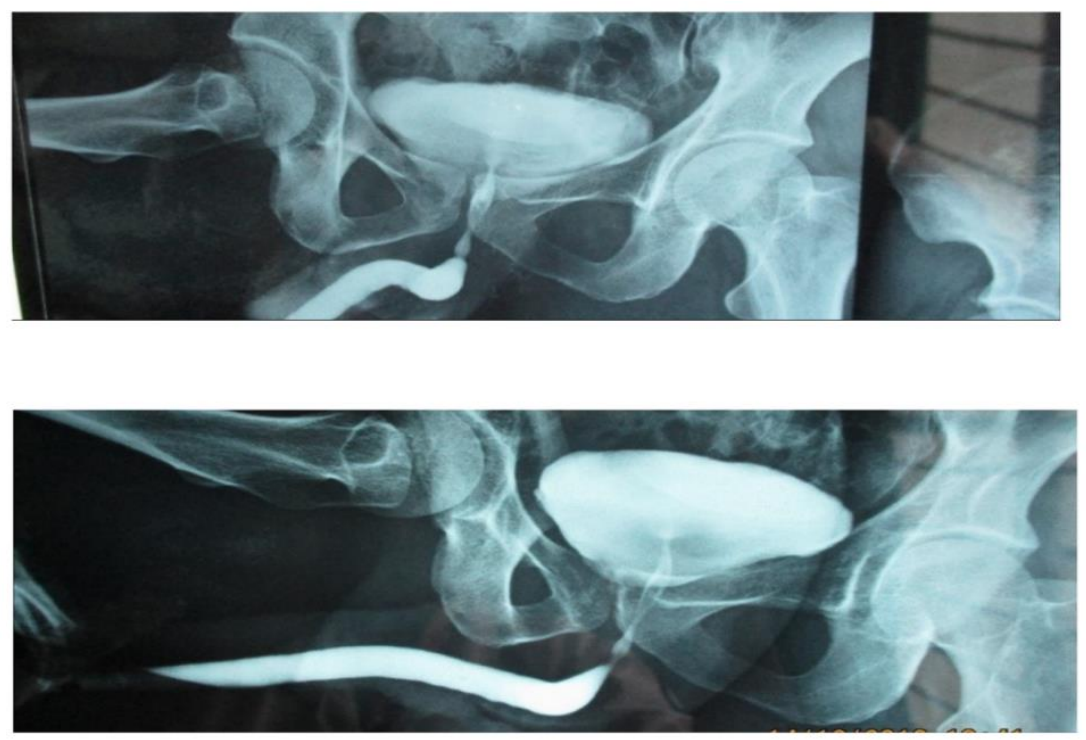

PRE \& POST TREATMENT RGU 
